\title{
Directions of Improving Civil Law Relations in Land Use
}

\author{
Larisa Vladimirovna Kudryavtseva
}

261 Turgeneva Str., Anapa, Russian Federation

Sergei Petrovich Stavilo

Vladimir Vladimirovich Ofisov

Alexander Nikolaevich Kachur

The branch of the Russian State Social University in Anapa, Russian Federation

\section{Doi:10.5901/mjss.2015.v6n3s3p115}

\section{Abstract}

The article considers the problems of land lots seizure for state and municipal needs and the problems of land raiding. It stresses that a special, mostly public law nature of relations concerning repurchasing of property for state needs, the parties of which are initially unequal, causes a number of problems. In particular, those problems come to the surface when a property purchase contract is concluded. In a number of cases, after the state agencies take steps to repurchase a land lot, a private owner takes legal action. Paying a compensation of equal value in advance to a private owner is yet another important issue. The article covers the problems related to execution of the right to land lots for private housing construction by certain categories of citizens and proposes to introduce the structural amendments to the legislation that would help solve the problems arising when land lots are provided for integral development for the purposes of housing construction. The article includes the directions of improvement of civil law relations with land lots.

Keywords: land lots, state and municipal needs, repurchasing, seizure, raiders, housing construction, responsibility of land lot owners.

\section{Introduction}

Land law relations represent a large and complicated issue, determined by the scope of relations between the subjects of different branches of law about land use and protection. In Russia, land has a special legal status, because it is considered a nationwide property. It is used and protected as a basis for life, activities, and well-being of the peoples of Russia.

In recent time, the issue of seizure of land lots for state and municipal needs has become a subject of constant attention of legislation authorities. A number of laws concerning the issue were passed. Introduction of these laws was caused by arising or sudden realization of some state need for construction of certain objects, and, afterwards, the law was urgently passed meant to satisfy that need in the context of territorial location of those objects. For example, the Federal laws as of Dec 01, 2007 No. 310-FZ "On organizing and conducting XXII Olympic Winter Games and XI Paralympic Winter Games 2014 in Sochi; on development of Sochi as an alpine resort, and on making amendments to individual laws of the Russian Federation"; as of May 08, 2009 No.. 93-FZ "On organizing the summit of the heads of states and state governments - the participants of the "Asia-Pacific Economic Cooperation" forum in 2012, on development of Vladivostok as a centre of international cooperation in Asia-Pacific region, and making amendments to individual laws of the Russian Federation"; as of Apr 05, 2013 No. 43-FZ "On specific features of regulating certain legal relations in view of annexation of territories to Moscow - the subject of the Russian Federation and the city of federal significance, and making amendments to individual laws of the Russian Federation"; as of June 07, 2013 No. 108-FZ "On preparing and conducting the World Football Championship 2018, FIFA Confederations Cup 2017 in the Russian Federation and making amendments to individual laws of the Russian Federation" (Povetkina E. L., 2014). It must be recognized that each of those laws was passed on a certain occasion, i.e. a certain construction project, whatever scope it had. In addition, this does not conform well to the very understanding of what the Law is. 


\section{Literature Review}

A special, mostly civil law nature of relations concerning purchasing of property for state needs, the parties of which are initially unequal, gives rise to a number of problems. In particular, the problems come to the surface when a property purchase agreement is concluded. In a number of cases, after the state agencies have taken steps to purchase a land lot, a private owner takes legal action, trying to force the public institution to conclude the specified agreement. However, the courts refuse to satisfy their requirements on the following grounds: the right to purchase a land lot and conclude the agreement is vested in a given institution, not in a private owner. Ownership right means that the owner has the authority to control their property (Gray K. J., Gray S. F., 1998).

Another important problem is the issue of paying a legally provided compensation of equal value paid in advance to a private owner (Obolonkova E. V., 2014).

For example, A. I. Kichko identifies the following problems that need improvement of regulation of land lot seizure for state and municipal needs:

1) "Allowed satisfaction of public needs by using a seized land lot by individuals;

2) The lack of a legal procedure of informing the parties concerned, except for the owner, about the upcoming seizure of a land lot;

3) Legal regulation of guarantees of an equally valued compensation paid in advance for a seized land lot;

4) The grounds for seizure of a land lot for state and municipal needs;

5) The procedure of seizure of a land lot for state and municipal needs; and

6) Determination of a purchase price for a land lot" (Kichko A. I., 2012).

The issue of determining the notion of state and municipal needs requires special attention. S. D. Afanasieva says: "Legal introduction of major limitations on land lots seizure for public needs rose a new problem that has not been fully solved yet: the public agencies began to use the institution of seizure as a practically universal tool for solving the tasks of social and economic effectiveness" (Afanasieva S. D., 2010). The most vivid examples, to her opinion, are the use of the right of seizure for satisfying non-material needs of citizens and optimization of fulfilling international obligations, as well as the use of the "economic development" term as a ground for legality of a seizure.

The essence of this problem, as applied to the Russian legislation, is revealed by $\mathrm{O}$. M. Kozyr. The author notes that the Civil Code of the Russian Federation fails to reveal the notion of state and municipal needs, to name any concrete grounds for seizure, and to provide the procedure of identifying the public needs that are considered a ground for a seizure. "This gap in the Civil code is partially bridged by the Land Code, which, adding to the rule in Clause 2, Article 279 of the Civil Code saying that the agencies authorized to make decisions on seizure and the order of preparing and making those decisions are determined by the federal land legislation, in Clause 1, Article 49 states that seizure can be implemented in exceptional cases related either to fulfilling international obligations of the Russian Federation, or location of certain objects of federal or municipal significance when there are no other options for their location. Among those objects, the Land Code of the Russian Federation names the objects that use atomic energy, objects of defence and security, objects of transportation, communication lines, informatics and communication of federal and regional significance, and objects of electric, gas, power and water supply of municipal significance. In Sub-Clause 3, Article 49 of the Land Code of the Russian Federation, the list is expanded by other circumstances in the cases set forth in the federal laws, and in a number of cases - in the laws of the subjects of the RF. In other words, the list is not complete" (Kozyr O. M.).

Due to the lack of the notion of state (municipal) needs in the current Civil Code of the Russian Federation, the modern literature offers the following definitions.

R. G. Arakelian defines the state and municipal needs "as the tasks of the state agencies and self-governing agencies set forth in the Constitution of the Russian Federation, Law on the Government of the Russian Federation, and Law on local self-governance". The author thinks that in that context, construction projects, which are not related to implementing federal target programs, cannot be considered as state and municipal needs. The author comes to the conclusion that seizure of a land lot for state and municipal needs presents a "nationalization (municipalisation) of an object of property implemented on the grounds of a court decision, with a compensation paid in advance for the cost of a land lot and other immovable property in the territory of a given land lot" (Arakelian R. G., 2007).

M. V. Balin defines seizure (purchase) of immovable property for state and municipal needs as actions aimed at forced compensated termination of the right of private ownership of the object of immovable property, implemented in exceptional cases in order to satisfy public needs, with a full compensation paid in advance for the cost of the property subject to alienation (Balin M. V., 2011).

The English law provides vast rights to use land as an essential sign of ownership right, which in common law 
sounds as follows: the person who owns land, owns everything from the sky to the centre of the earth (Gray K. J., Gray S. F., 2005). According to Christopher Rodgers, professor at the University of Newcastle, nowadays that principle is very hard to recognize, especially related to the rights to use land; therefore, it rather has some virtual meaning and definitely contributes to confusion. It is symbolic that common law does not recognize any qualification of the right of ownership, which could impose on the owner obligations concerning environmental protection and others, as characteristic features of the right of ownership (Rodgers C., 2009).

E. L. Povetkina strongly objects to using (keeping the term inherited from the Soviet times) the "state and municipal needs" term: "For most of our citizens, this term means the interests of the state and municipal authorities that, it should be admitted, in the modern perception, do not equal to something for exercising of which that institute is meant - the public interest, interest of a large number of individual members of society" (Povetkina E. L., 2014).

There is a contrary opinion, according to which the expansion of the list of grounds for forced termination of the right of private ownership of land lots, in practice can only damage the rights of private owners protected by law. According to some authors, "one can legally classify those public needs and establish the procedure of decision-making by the public agencies when land lots are seized into federal ownership, ownership of subjects of the Russian Federation, and municipal ownership, accordingly. However, in this case there will arise the opportunity to seize land lots in the favour of individuals, e.g. in order to build an elite apartment building or a church. In any case, the level of guarantees of the rights of private owners will be significantly reduced, which is unacceptable in our developing legal state (Anisimov A. P., Ryzhenkov A. Y., Sotnikova M. S., 2010).

A. P. Anisimov, A. Y. Ryzhenkov, and M. S. Sotnikova are of the opinion that based on the existing theory and practice of seizure of land lots for municipal needs, there is a need for the following academic classification of cases when a land lot cannot be seized:

- Seizure of land lots for municipal needs on the grounds that are directly set forth in article 49 of the Land Code of the Russian Federation;

- Seizure of land lots in the cases set forth in federal laws (e.g., based on the agreement on development of a built-up territory);

- Seizure of land lots in order to locate public objects built to boost the international reputation of Russia (Anisimov A. P., Ryzhenkov A. Y., Sotnikova M. S., 2010).

K. P. Golovanov also concludes that there is a need for a single mechanism of legal regulation of relations concerning seizure of land lots for state and municipal needs. Therefore, a special federal law to regulate the abovementioned relations must be developed and passed. In order to bridge the gaps and eliminate the drawbacks of the Russian legislation, the author thinks that the new federal law to include the following:

1) Definition of "seizure of land lots for state and municipal needs", due to the lack of such;

2) Definition of "state and municipal needs";

3) Rules that provide the grounds for land lots being seized for state needs. These grounds may include:

- Conducting large-scale state events;

- Conducting international forums with participation of heads of states, etc.

The author emphasizes that the format and exact name of events must be determined by a resolution of the Government of the Russian Federation by categories (e.g., international forum and International forum of heads of states, or large-scale state events and Winter Olympic Games in Sochi, etc.).

Large-scale state events and international forums can be classified by the time needed for their preparation:

- From two to four years - the events that need urgent preparation (in that case, a special period of notification to inform a private owner about seizure of a land lot for state and municipal needs can be introduced, i.e. seven days since the decision was made);

- From four to eight years - the events that do not need urgent preparation (in this case, the period of notification can be increased (Golovanov K. P., 2013).

Analysing that point of view, it can be emphasized that the author considers only large-scale mass entertainment or state events as the cases for seizure of land lots that must be set forth in the legislation. In conclusion, it should be noted that nowadays there is a clear need for either passing an individual law about seizure of land lots for state (municipal) needs, or adding a required section to a special law on purchasing property by the state. Besides clauses on property seizure for state (municipal) needs, that law could also include clauses on requisition and nationalization.

It also should be noted that the approach that gives to the courts full freedom in determining the cases of seizure of land lots for state (municipal) needs is unacceptable for Russia's reality, because the lack of a rigid criterion at the initial stage may entail a number of legal controversies. Later, when those controversies will be settled, excessive freedom of courts may entail judicial errors and abuse of rights. 


\section{Materials and Methods}

In the context of the above-mentioned, two way-outs seem possible. The first one is to introduce at the federal level (i.e. directly in the Civil Code of the Russian Federation) an exhaustive list of grounds for seizure of land lots. The second one is to set forth in the Civil Code of the Russian Federation several criteria (principles), which would allow the court, with a sufficient extent of certainty, for deciding whether in a given case a land lot is seized for state (municipal) needs. In addition, a special federal law on seizure should include a provisional list of cases that conform to a given criterion, and the procedure of seizure on the grounds of that criterion.

As it is hardly possible to use the first approach in order to describe in all detail all cases of possible seizure of land lots for state (municipal) needs for a long-term period, the second approach seems to be more feasible and providing space for court judgment, but in strict limits.

We think that the legislative experience of the Republic of Kazakhstan may be useful for improving the Russian legislation. Article 62 of the Law of Republic of Kazakhstan as of March 01, 2011 No. 413-IV "On state property" (Chapter 6 , Section 2) sets forth the key principles of performing forced alienation of a land lot or other immovable property due to seizure of a land lot for state needs. Thus, a forced alienation of a land lot or other immovable property due to a seizure of a land lot for state needs presents an exceptional case of alienation of property owned by individuals and non-state legal entities and can be performed only if all other possible cases of property alienation set forth in the Civil Code and laws of the Republic of Kazakhstan cannot be applied. It is prohibited to perform a forced alienation of a land lot or other immovable property due to seizure of a land lot for state needs, if another (alternative) way of satisfying state needs is available. Any seizure of property pursuing commercial goals of non-state legal entities and goals of satisfying non-state interests, or other seizure of property that fail to follow from the goals of performing state functions or pursue socially significant goals cannot be recognized as a seizure for state needs. In those cases, seizure of property is allowed under the agreement between its owner and a person that pursues commercial goals in the form of a contract of purchase and sale of property. Finally, forced alienation of a land lot or other immovable property due to seizure of a land lot for state needs is allowed only in the scope needed for satisfying the needs of the state.

Those principles are of significance and can be introduced into the Russian legislation.

Another acute problem nowadays is land raiding. Having learning that there is a vacant land lot, unprincipled citizens try to benefit from the situation. They apply to receive that particular lot, without having any intention to use it as intended. The goal of such citizens is to receive money from a real contender for the land lot. For a certain amount of money, the raider withdraws own bid for the land lot, and another person obtains it. However, if that person does not accept the conditions of raiders, then, according to the law, the land lot - if there are several bids - to be put out to tender. Before that, the municipality must form it, enlist it into the cadastre, and conduct an independent evaluation. All those procedures require unbudgeted expenses of the local budget. As a result, land allocation is suspended. In addition, the procedure is set forth in the legislation in such a way that the municipal institution has no legal grounds to apply to the law enforcement agencies. It is evident that a way out of that situation must be found. According to Linton Caldwell, the traditional concept of the right of land ownership impedes the rational use of land, prevents development and protection of environment, and confuses innocent people who believe to be protected by it. There is a need for a new conceptual basis for the right to use land and the policy, in order to reconcile lawful rights of landowners with the interests of society in maintaining a high quality of environment (Caldwell L. K., 1974.).

\section{Results and Discussion}

Nowadays, according to Article 30.1 of the Land Code of the Russian Federation, if a land lot is provided for housing construction from the lands owned by state or municipal authorities, the law does not require a mandatory layout of the lot where an object to be located.

The proposal about expanding the list of documents attached to the application to provide a land lot for individual housing construction is not secured in the legislation. Paragraph 1, Clause 3, Article 30.1 of the Land Code of the Russian Federation to be expanded with the sentences specifying the following: "Applications from citizens to provide them with a land lot for private housing construction shall be accompanied by a layout (in the form of a graphic map) of a land lot where an object will be located. The borders of the land lot in question must be plotted on the layout in a proper scale, with distances to existing buildings and structures and the measurements along the perimeter of the land lot".

Thus, a raider will not be able to file several bids for all land lots for private housing construction, information about which is published in the media. To do so, they would have to bear significant expenses to draw a layout to show the borders of each land lot, they made a bid for, without any guarantee that the money spent will be returned to them in the 
future.

Article 38 of the Land Code of the Russian Federation contains the procedure of holding a tender for acquiring land lots or the right to conclude a lease contract, which needs to be expanded with inspection by federal agencies and prosecutor's office of bidding citizens with respect to repeated participation in other tenders.

The proposal about introducing the opportunity to lease land lots of common use is not secured in the legislation.

Clause12, Article 85 of the Land Code of the Russian Federation prohibits privatization of land lots, which fall into the category of lands of common use. However, there are no direct limitations on their lease. As a result, there is no universal judgment passed by arbitration courts on that issue.

This approach seems not quite right, because the court passes judgments that break its uniformity. Reference to the same rule becomes the ground for precisely opposed court judgments. There are two main mutually exclusive positions, which, however, exist in real life.

According to the first one, it is prohibited to lease a land lot from the lands of common use, because this contradicts the rule in Clause 12, Article 85 of the Land Code of the Russian Federation. The contrary position is that leasing a land-lot from the lands of common use does not contradict Clause 12, Article 85 of the Land Code of the Russian Federation, under the condition that it does not exclude the possibility of common use. However, not any lease implies receiving an exclusive right to use a land lot.

Therefore, if individual use, according to the lease agreement, does not exclude the possibility of common use, there is no contradiction with the law. The grounds for prohibiting lease of such land lots seem unpersuasive. Until this issue is solved at the federal level, the courts will not pass a universal judgment on such cases.

We think that Clause 12 of Article 85 of the Land Code of the Russian Federation needs to be expanded with the following sentence: "A lease contract for a land lot of common use is concluded on the condition of providing citizens with a free access to the land lot".

That addition will allow fully protecting the rights of people concerned, adjusting the court practice in settling that category of cases, and bringing the rules of land legislation to conformity.

According to Clause 5, Article 22 of the Land Code of the Russian Federation, "A lessee of a land lot, except for those lessees who are the residents of special economic zones, is entitled to transfer their rights and obligations under the land lease contract to the third party, including to pledge the lease rights and use them as a contribution into the authorized capital of a business partnership or association or as a share to a production cooperative within the term of the land lease contract, without consent of a land lot owner, under the condition of notifying them, unless otherwise is stated in the land lease contract. In the specified cases, a new lessee of a land lot becomes liable to the lessor under the land lease contract, except for pledging the lease rights. In that case, there is no need to conclude a new lease contract".

Several remarks need to be made about the rule about transfer of responsibility to a new lessee of a land lot. Indeed, the actual use of a land lot is performed not by the initial lessee, but a new person that actually uses a land lot, and that person is imposed with obligations to use a land lot as intended, take measures to protect the land, prevent pollution, etc. However, the specified obligations are of public nature, responsibility for non-execution of which is set forth in special legislation, and are not related to the obligation that arises from the lease contract. Land legislation does not include concrete violations of law in the area of land protection and use and refers to criminal law and administrative offences legislation, whereby a person who committed a violation is exclusively held liable. It seems that a lessee remains liable to a lessor (owner) for non-execution of contractual obligations. Therefore, the rule in Clause 5, Article 22 of the Land Code of the Russian Federation must be brought to conformity with the civil legislation.

Clause 5, Article 22 of the Land Code of the Russian Federation, after the words "In the specified cases, a person liable under the contract to the lessor..." seems appropriate to state with the following wording: "...becomes a new lessee of a land lot, except for pledging lease rights".

We think that such an addition will secure conformity of the rules of civil and land legislation and enhance the discipline of subjects of land relations. In addition, those amendments will help to overcome the problems related to providing land lots for their integrated development for the purposes of housing construction. Changing a subject structure in the obligation must not infringe on the interests of people that invest money in co-invested construction of real estate objects. Therefore, the proposal will help to avoid unreasonable increases in prices for newly built objects of coinvested construction.

It should be noted that the law does not set forth the consequences of the lack of consensus between co-owners of buildings (premises) located on an indivisible land lot about the fate of a land lot. According to paragraph 1, clause 5 , article 36 of the Land Code of the Russian Federation, "To acquire rights to a land lot, individuals or legal entities specified in this article file together an application for acquisition of the rights to a land lot to the executive authority or a self-governing agency specified in Article 29 of this Code". 
The current situation makes it difficult to solve the issue concerning re-purchase of a land lot or conclusion of a land lease contract in case of division of co-owners' opinions. It leads to a deadlock situation, because establishing a housing owners' partnership is problematic and is not determined by a concrete term, lease of a share in the right of ownership is not allowed by the land legislation, a land lot cannot be purchased without consent of all owners, perpetual use is not allowed by the law. As a result, land ownership is unlawful and the use of a land lot is illegal. Therefore, this rule needs to be amended and brought to conformity with other provisions of law.

Therefore, we propose to add to paragraph 1, clause 5, article 36 of the Land Code of the Russian Federation the following sentence: "If the specified people cannot come to a consensus about purchasing or leasing a land lot, a land lot is leased to them with the right of subsequent purchase".

That addition will give individuals an opportunity to exercise their rights to a fuller extent, bring the court practice to conformity, and implement a principle of universal fate of land lots and objects that are strongly related to them. As a result, this will secure a lawful use of a land lot by all co-owners of buildings (premises) located on it, with retaining the possibility of subsequent purchase of the land lot.

The proposal about introducing the procedure of priority allocation of a land lot for private housing construction to certain categories of citizens is not secured in legislation.

Land lots for construction from the lands in state or municipal ownership are provided for ownership or lease in the manner and on the grounds set forth in article 30 of the Land Code of the Russian Federation, by the means of a tender. At the same time, according to Article 17 of the Federal Law "On social protection of disabled people in the Russian Federation", disabled people and families with disabled members are granted the priority right to receive land lots for private housing construction. At the same time, the procedure of priority allocation of land lots is not set forth in the legislation. However, according to Clause 2, Article 30.1 of the Land Code of the Russian Federation, "Land lots for housing construction or the right to conclude lease contracts for land lots for housing construction are sold at tenders, except for the cases set forth in sub-Clauses 5 and 5.1 of Clause 1, Article 24; Clause 2.1 of Article 30; and Clause 27 of Article 38.1 of this Code".

At present, it does not seem possible for certain categories of citizens to exercise their priority right to receive a land lot, due to the lack of a special procedure of land lot allocation to those categories of citizens for private housing construction in the land legislation. The specified problem leads to numerous judicial controversies.

We propose to add to Clause 2, Article 30.1 of the Land Code of the Russian Federation the following words: "... as well as in case of allocating land lots for private housing construction and construction of a dwelling house on household land lots of a private plot or selling the right to conclude a lease contract for land lots for housing construction to certain categories of citizens set forth in federal laws and laws of the subjects of the Russian Federation".

\section{Conclusions}

Thus, the land legislation will be expanded with a rule that implies practical implementation of clauses not only of Article 17 of the Federal Law "On social protection of disabled people in the Russian Federation", but also other laws that secure the right to priority allocation of a land lot to certain categories of citizens, and will allow them to avoid applying to law enforcement agencies in repeated attempts to exercise the right given to them but not provided with legal mechanisms.

The proposal to raise a land tax rate for not using agricultural lands as intended is not secured in the legislation.

According to Paragraph 2, Sub-Clause 1, Clause 1 of the Tax Code of the Russian Federation (part two), land tax rates must not exceed: " 0.3 per cent for the land lots that are classified as agricultural lands or lands within agricultural zones in settlements and used for agricultural production...". At the same time, according to Sub-Clause 2, Clause 1 of the Tax Code of the Russian Federation (part two), and land tax rates must not exceed: "1.5 per cent for other land lots". In addition, Article 85 of the Tax Code of the Russian Federation (part one) that states the obligation of state agencies, institutions, organizations, and executives to provide tax authorities with information about organizations and individuals, does not oblige them to provide tax authorities with information about revealed violations connected with non-use of a land lot from agricultural lands for agricultural production, planting of shelter forests, research and development, educational and other purposes related to agricultural production.

At present, a significant amount of agricultural lands is not used as intended. According to Ronald Coase, a famous economist and a Nobel Prize winner, the rights of a landowner are not absolute. A landowner cannot even dig the ground and take it to another place. This is explained by special rules established by the state (Coase R. H. 1960).

Therefore, the tax legislation needs to be expanded with a clause about enhancing penalties for landowners for idle agricultural lands through increasing a tax burden. To solve the specified problems, we propose the following amendments: 
1) To add to Article 85 of the Tax Code of the Russian Federation (part one), Clause 9.3 specifying the following: "9.3. Agencies that implement state inspection of lands, within no more than 10 business days since the order was issued to correct the revealed violation related to non-use of a land lot from agricultural lands for agricultural production, planting of shelter forests, research and development, educational and other purposes related to agricultural production, to provide a tax authority having jurisdiction over a given land lot with information about its non-use. If the agencies implementing state inspection of land establish the fact of correction of the specified violation, the respective information must be provided to a tax authority having jurisdiction over a given land lot within no more than 10 business days since the fact was established

2) To add to Article 396 of the Tax Code of the Russian Federation (part two), which states the procedure of calculation of a land tax and advance payments on land tax, Clause 17 specifying the following: "In regard to land lots classified as agricultural lands and lands within agricultural zones in settlements not used for agricultural production, planting of shelter forests, research and development, educational and other purposes related to agricultural production, land tax is calculated at the rate set forth in Sub-Clause 2, Clause 1, Article 394 of this Code over the entire tax period, during which the land lots were not used, till the revealed violations are corrected".

We think that those law-making initiatives will contribute to idle agricultural lands being used for agricultural purposes and increase the effectiveness of their use. In addition, local budgets can be replenished: land tax is contributed in full into the budget of the municipality, in the territory of which a land lot is located.

Thus, based on the undertaken research of acute problems of legal regulation of land relations in the Russian Federation, the need for further improvement of the land legislation can be concluded.

\section{Acknowledgements}

The authors acknowledge the heads of the branch of the Russian State Social University in Anapa, in the name of Doctor of political sciences and Professor Elena Alexandrovna Tsybulskaya.

\section{References}

Afanasieva, S. D. (2010). Seizure of land lots for public needs in Russia and the USA: some acute issues of protection of constitutional rights // Sravnitelnoe konstitutsionnoe obozrenye. No. 1.- pp. $42-45$.

Anisimov A. P., Ryzhenkov A. Y., Sotnikova M. S. (2010). The right of municipal ownership of land lots in the Russian Federation: Theory and practice: Monograph. - M.: Novyy Index. - 275 p.

Arakelian, R. G. (2007). Reservation and seizure of land lots in the mechanism of legal regulation of property relations: Synopsis of a thesis. ...PhD in Law. - Krasnodar. - $102 \mathrm{p}$.

Balin, M, V. (2011). Civil law grounds for forced termination of the ownership right: Synopsis of a thesis. ...PhD in Law. - Krasnodar. - 98 p.

Caldwell, L. K. (1974). Rights of Ownership or Rights of Use? - The Need for a New Conceptual Basis for Land Use Policy // William and Mary Law Review. Vol. 15. No. 4. pp. $759-760$.

Coase, R. H. (1960). The Problem of Social Cost. 3 J. L. \& Econ. 1.

Golovanov, K. P. (2013). Seizure of land lots for state and municipal needs: Problems of legal legislation // Imushestvennye Otnoshenya v Rossiyskoy Federatsii. No. 10.- pp. 72-76.

Gray, K. J., Gray S. F. (1998). The Idea of Property in Land in Themes and Perspectives. Oxford University Press, pp. 15 - 51.

Gray, K. J., Gray S. F. (2005). Elements of Land Law. 4th ed. OVP.

Kichko, A. I. (2011). Forced termination of ownership right to land lots: Synopsis of a thesis. ...PhD in Law. Krasnodar.- 112 p.

Kozyr, O. M. (2011). Seizure of land lots for state and municipal needs // Development of major ideas of the Civil Code in the current legislation and court practice: Compilation of articles / Edited by S.S. Alexeeva. - M.: Statut. - pp. 156-161.

Land Code of the Russian Federation as of Oct 25, 2001 No. 136-FZ (as amended on 21.07.2014) //Official Gazette of the Russian Federation. - 2013. - No. 30 (part I). - p. 4080.

Obolonkova, E. V. (2014). Seizure of land lots for state and municipal needs: the problem of identifying cases of possible seizure // Zakonodatelstvo i ekonomika. No. 8. - pp. 40 - 47.

Povetkina, E. L. (2014). Seizure of property for public needs: civil principles and modern tendencies // Zakon. No. 2. - pp. 41 - 60.

Rodgers, C. (2009) Property Rights, Land Use and Rural Environment: A Case for Reform. Land Use Policy, 265, pp. 134 - 141.

Tax Code of the Russian Federation (part two) from 05.08.2000 No. 117-FZ (as amended on 29.12.2014) (amended and revised, came into effect on 01.01.2015) // Official Gazette of the Russian Federation. - 2000. - N 32. - p. 3340 
ISSN 2039-2117 (online) ISSN 2039-9340 (print)
Mediterranean Journal of Social Sciences MCSER Publishing, Rome-Italy
Vol 6 No $3 \mathrm{~S} 3$ May 2015 